\title{
HATE AS THE ULTIMATE FORM OF INTERGROUP CONFRONTATION
}

\section{Bielavin S. P.}

\section{INTRODUCTION}

Number of interrelated crises that occur simultaneously worldwide show global and systemic world processes. The crisis of civilizational choices, the cultural crisis, rising levels of social and economic inequality, rising levels of social tension, aggression, and violence all lead to a social inquiry to uncover the essence of social perceptions such as hatred.

Psychology has long "shied away" from the study of a phenomenon so important to the life of every person and society as a whole. Until recently, the topic of negative attitudes and attitudes in psychology was limited to studies of anger, hostility and aggression, as well as studies of social discrimination and prejudice.

According to G. Allport, prejudices are so constant, despite the large amount of information that contradicts them, precisely because of the emotional component. Most likely, hatred forms the emotional basis of most human prejudices and prejudices ${ }^{1}$.

Since 2001, the US (Gonzaga University) has published an interdisciplinary journal of hate studies. In 2005. the first collection of articles on hate psychology was published. And in 2008, the first symposium on the psychology of love and hate was held at Tartu at the 14th European Conference on Personality Psychology.

The rather poor development of phenomenology and hate issues is obviously linked to a certain taboo of discussing this topic in society, as well as to a number of moral, ethical and organizational problems associated with research. For example, in group studies, group members usually not only overestimate the own and other group, but also deny the presence of socially disapproving feelings for "others".

In scientific sources, many terms are used to describe "alien": "stranger", "enemy", "marginal", "monster", etc. Analytically, the differences between them are indistinguishable, which makes it possible to

\footnotetext{
${ }^{1}$ Allport G.W. The nature of prejudice. Garden City, NY: Doubleday Anchor Books, 1958.
} 
apply the general concept of "alien" to an ethnic group that is subject to discriminatory practices that have real consequences for an "alien" ethnic group in the form of manifestations of interethnic intolerance. To give at least some legitimacy to these manifestations of intolerance, ethnic groups are transformed into "alien" by the significant role of norms and values that dominate society, and to some extent make the phenomenon of ethnic intolerance for society, so to speak, "invisible",

\section{Hate as a social-psychological category}

At the moment, there is little research in psychology on a chosen topic, which may be because there is no commonly accepted definition of hatred. Some researchers suggest that hate is an emotion caused by situational factors, and a number of other psychologists believe that hate is a personality trait that has been stable for a long period of time.

Aristotle defined hate by comparing it to anger. The philosopher believed that hatred can occur even without a previous crime and can be targeted at different groups. However, anger can only be directed at individuals. In addition, anger arises from pain while hatred can be no painful for the enemy.

In contrast, in the seventeenth century, the Dutch rationalist philosopher Benedict Spinoza wrote: "Love is nothing but pleasure (joy) accompanied by the idea of an external cause, and hatred is nothing but dissatisfaction (sadness) accompanied by the idea of an external cause. Further, we see that the one who loves must strive to have a favorite object of existence and keep it; and vice versa - the one who hates, seeks to remove and destroy the object of his hatred"3.

Modern ideas of hatred also differ in content. Some researchers defined ayut hatred as intense and irrational emotion, impairment of perception, because it is misleading and requires thought objects, which can be attached. Others believe that hate is not always irrational. If the enemy seeks ... to destroy you, your loved ones, or your country, hatred can be an adaptive and rational response that helps to survive. That is, modern scientific thought determines the ambivalent essence of the delineated feeling: on the one hand, irrationality, and on the other rationality and the need to experience hatred.

\footnotetext{
${ }^{2}$ Чужой [Электронный ресурс]. - Режим доступа : http://ecdejavu.ru/c/Chuzoy.html.

${ }^{3}$ Спиноза Б. Избр. произв.: В 2 т. Т. 1. М: Политиздат, 1957. С. 467-468.
} 
Kimberly Dozier suggested that hatred evolves from the ancient survival instinct. It includes intense at once, anger and stereotypes. In this sense, hate in an aggressive form is a hostility that reflects the extreme form of fear. However, when experiencing hatred, the individual's reaction is to fight, not run, to flee, as is usually the case with fear. The researcher notes that hatred is a kind of hypertrophied anger, fear; an experience that in the past has helped mankind to prevent dangerous situations, but today is somewhat outdated for the public order. Thus, hatred is a disorder that disrupts social functioning in today's world ${ }^{4}$.

A. Kernberg believes that hatred is not necessarily a pathological manifestation. When it appears in response to real and objective dangers, it is a normal form of anger aimed at eliminating the threatening object. In addition, feelings of hatred are often altered and heightened by other, more unconscious, emotions, such as a thirst for revenge. Thus, hate is a complex aggressive affect that is chronic and stable, unlike rage or anger. Its main purpose is to destroy the object of hatred ${ }^{5}$.

Paul Ekman described hatred as emotionally colored relationships like love. Love and hate are more resilient than other feelings, but they have a complex structure that involves a lot of emotions ${ }^{6}$.

According to R. Sternberg, hatred potentially consists of three components: denial of closeness, passion and obligation. The denial of closeness is that hatred of someone is disgusting. Passion expresses itself as intense anger or fear in response to a threat. The obligation is characterized by a deterioration in the perception and devaluation of the hateful group or object based on contempt. These three components lead to seven different types of hatred, depending on certain combinations ${ }^{7}$.

Typically, the subject perceived hatred that hate as social exceed enyy (asymmetry of power) entity (individual or group) that makes violence against others ${ }^{8,9}$. The notion of power asymmetry implies that hatred does not have effective protection against the object of hatred and against

\footnotetext{
${ }^{4}$ Kimberly Dozier Breathing the Fire: Fighting to Survive, and Get Back to the Fight.

${ }^{5}$ Кернберг О. Отношения любви: норма и патология / О. Кернберг. Пер. с англ. М.Н. Георгиевой М.: Независимая фирма «Класс», 2000. - 256 с. - (Библиотека психологии и психотерапии, вып. 76).

6 Экман, Пол. Психология эмоций / пер. с англ. В. Кузин. - СПб.: Питер, 2010. - 336 с.

${ }^{7}$ Sternberg R.J. (ed.). The psychology of hate. Washington, DC: APA, 2005.

${ }^{8}$ Fitness J. Anger in the workplace: An emotion script approach to anger episodes between workers and their superiors, co-workers and subordinates // J. of Organizational Psychol. 2000. V. 21. P. 147-162.

${ }^{9}$ McKellar P. Provocation to anger and development of attitudes of hostility // Brit. J. Psychol. 1950. V. 40. P. 104-114.
} 
humiliation, physical pain, or the threat to the well-being and values that flow from it.

It must be emphasized that in order to develop hatred, violence and / or threats that come from hatred must be continuous or repeated. A one-off attack only causes anger or other fleeting emotion. Only repeated attacks or conflicts can be decisive in developing hatred for a particular person or group $^{10}$.

D. Bar-Tal believes that victims of violence are more likely to be hateful than abusers, but in prolonged conflicts both sides consider themselves victims of violence ${ }^{11}$.

G. Breslav modified R. Sternberg's model, reducing it to two-factor: passive hatred (fear, avoidance, distance) and active hatred (condemnation, anger, desire to punish $)^{12}$.

Hate is seen in linguistics as a discursive practice. SA Kolosov brought out the following manipulative strategies of hate discourse: metaphorical forms of nomination of We and They of groups, stereotyping of discourse, strategy of finding the "go-go", narrowing or expanding the semantic meanings of words-concepts, ignoring facts and objective data, changing the source speaking, using vocabulary with implicit argumentative meaning. It also identifies two major functions of these strategies: 1) the discursive construction of hatred (by updating the metasense of "hatred"); 2) the legalization (normalization) of hatred".

The quality and concept of hate semantics, ways of its linguistic realization, binary oppositions of love / hate in different linguistic cultures are analyzed.

Neuroscience attempts to identify neurological markers of hatred. S. Zeki and J. P. Romaya ${ }^{14}$ conducted an experiment by demonstrating a photo of people hated by them and scanning their brains with a functional magnetic resonance imaging scanner. The results revealed a unique

\footnotetext{
${ }^{10}$ Baumeister R.F., Butz D.A. Roots of hate, violence, and evil // Sternberg R.J. (ed.). The psychology of hate. Washington, DC: APA, 2005. P. 87-102.

11 Bar-Tal D. Collective memory of physical violence: Its contributions to the culture of violence // G. Salomon, B. Nevo (eds). Peace education: The concept, principles and practice around the world. Mahwah, NJ: Lawrence Erlbaum Associates, 2002, P. 27-36.

${ }^{12}$ Breslavs G., Tyumeneva J. Toward operationalization of the hate concept: Is hate an opposite to love? // The paper presented at the 14th European conference on Personality, Tartu, July 16-20, 2008.

13 Колосов С.А. Манипулятивные стратегии дискурса ненависти / С.А. Колосов // Критика и семиотика. - Вып. 7. - Новосибирск, 2004. - С. 248-256.

${ }^{14}$ Semir Zeki, John Paul Romaya. Neural Correlates of Hate / Plos One. https://journals.plos.org/plosone/ article?id=10.1371/journal.pone.0003556
} 
neurological pattern of activity. The results showed that hate activates aggression-related brain regions and areas responsible for preparing the body for movement that translate aggression into action.

It turns out that hatred also activates the other two brain regions, the shell and the islet lobe associated with passion, romantic love. Hatred also partially activates both the cerebral cortex and subcortical areas, in particular, the premotor cortex, which is involved in the planning of actions and their execution.

So, summing up the variety of definitions, taking into account contemporary views, let us try to determine that hatred is a persistent negative feeling of the subject directed at another person, group of people, inanimate object or phenomenon, which poses a real or perceived threat to the needs, beliefs or values object. This feeling is characterized by the constant desire of the subject to inflict as much pain or suffering (up to the destruction) of the object of hatred, real or imagined, as possible.

\section{The place and role of the hated category in the system of conflictogenic social categories \\ 2.1 "Own-stranger" as a predictor of hatred}

Renowned psychologist P. M. Shyhiryev believes that the prospects of social psychology, associated with the study of the interaction of the individual and society as a body, to be performed at the level of reality that is conditioned by human values. They give meaning to the existence and behavior of a person in his interaction with other people, the world and himself. He understands social interaction as a connection of social actors (individual and collective), which is psychologically realized in relation to themselves, to each other and to reality ${ }^{15}$.

Mr. M. Shyhiryev notes that signs of social interactions unfold in the exchange system and subject - to - subject and subject - to - object interactions and attitudes. He defines the subject of social psychology "as a study of attitudes (appraisals) to relationships (connections)." $\mathrm{He}$ emphasizes the need to study the processes of the emergence, functioning and dying away of forms of objectification of value attitudes in social exchange, in real life.

\footnotetext{
15 Шихирев П.Н. Современная социальная психология / П.Н. Шихирев. - М. : ИП РАН, КСП+, Академический Проект, 1999. - 447 с.
} 
One of the phenomena of social perception that directly related to categories hatred opposition is "own-stranger." It represents one of the fundamental oppositions in the scientific picture of the world in, the basic way of categorizing social being, the separation of the world perceived as "one's own", close, safe, from the world, evaluated as "alien", unknown, dangerous, the way of organizing social reality, which is subordinated to other types of social actions and human relationships ${ }^{16}$.

In the general philosophical, cultural, social and psychological context, the category "own - stranger" reflects one of the basic oppositions that arose and developed from the period of pre-scientific knowledge about the world, about oneself, about others, which causes the separation in the general picture of the world that is perceived by the individual and the group in general as "his" (understandable, not threatening physical existence and mental well-being) from another conception of "alien" environment: unfamiliar, incomprehensible, and therefore allegedly necessarily threatening to person, for reference group, community. Moreover, from the perspective of social psychology concept of "own stranger" is defined and understood as opposed to "we - they" and the division into "us" and "them"

The oposition of "own - stranger" is the most certain value ratio, which serves as a social orientation. Such a contradiction is the basis of the paradox of the perception of the "other".

The concept of "own - stranger" is used in the theories of intercultural communication, in cross-cultural studies, which defines the concept of ethnos as a group of people who have similar knowledge about life, but the forms of its storage and transmission to the next generations are different, which makes it possible to be aware of each other as "strangers", that is,"not like ones".

In social psychology, the opposition of "own - stranger" underlies the analysis of the features of interpersonal and intergroup perception, in particular in the sphere of communication of national identity and language.

In the sociological aspect, opposition "own - stranger" is explored as a manifestation of the internal differentiation of society, which defines the relationships between individual social groups.

\footnotetext{
${ }^{16}$ Белинская Е.П., Тихомандрицкая О.А. Социальная психология личности : учеб. пособ. для вузов / Е.П. Белинская, О.А. Тихомандрицкая. - М. : Аспект Пресс, 2001. - 301 с.

${ }^{17}$ Гумилев Л.Н. Этногенез и биосфера Земли / Л. Н. Гумилев. - СПб. : Ленинградское Изд-во, 2011. 560 c. - C. $25-27,92-96$.
} 
The ability to divide into "own - a stranger" is given to the person because he or she is necessary for its development. As early as childhood, the child begins to differentiate himself from the outside world, such as "I" from "not - I", "his - not his" body. In order to learn how to control one's body, a child must first understand where its boundaries are. When it becomes clear with the limits of one's own body, the child switches to others, setting the boundaries of "own - stranger" emotional space, especially with those who are near the moment of birth. Therefore, a very important achievement in the child's mental development is the so-called emotional separation from the parents.

Separating their feelings and desires from others, a person gradually clarifies their emotional boundaries. That is, it learns to perceive itself as an independent person, capable of making decisions and be responsible for them. In adolescence, the definition begins with the worldview, with ideology, etc., but usually it comes down to associations of interests.

In the Ufa laboratory of high-tech psychology, a group of scientists has proposed a quadrupole model of the structure of the "own - stranger" archetype, which, in the authors' opinion, opens up new possibilities for emergency diagnostics and management of deep social behavior. Researchers G. A. Aminyev, E. G. Aminyev, M. N. Ivanov, and considered the archetype of "own - stranger" as a psychological formation that includes four individually-typological variations depending on the direction and tropism antitropism to "theirs" and "strangers", namely: tropism to "theirs" by positive qualities; antitropism to "strangers" by negative qualities; a complex of marked tropism to "one's own", which is combined with antitropism to "alien" (that is, it is an intolerant attitude towards "alien"); various paradoxical attitudes (tropism to "strangers" and antitropism to "one's own", or disorganization of the archetype, such as "Stockholm Syndrome"); antitropism to both "theirs" and "strangers" (alienation) $^{18,19}$.

To some extent, the problem of the "one - stranger" dichotomy is also reflected in the linguistic concept as a thesaurus concept. Thesaurus

\footnotetext{
18 Аминев Г.А. Историко-психологические предпосылки межцивилизационных конфликтов: юнгианский подход / Г.А. Аминев, Э.Г. Аминев, Цзинь Ван (г. Пекин), М.Н. Иванов, Л.Р. Шафикова // Пространство и время в восприятии человека: историко-психологический аспект : матер. XIV Mеждунар. науч. конф. - СПб. : Нестор, 2003. - Ч. 1. - С. 7-9.

19 Иванов М.Н. Типообразующие соотношения архетипа «свой/чужой» и склонности к терроризму: психофизиологические предикторы: автореф. дис. на здобуття наук. ступеня канд. психол. наук : 19.00.02 «Психофизиология» / М.Н. Иванов - Уфа, 2004. - 22 с.
} 
concept developed by Val.A. Lukov and V.A. Lukov illustrates, first, that the dichotomous distinction between "own" and "stranger" is the structuring principle here; second, and "their" and "foreign" with varying intensity length, are certain zones, concentric circles around the subject, some of which are closer, others farther from the center and in this case "over own" "less own" (oposite "less stranger" and "more stranger"); third, a thesaurus has a built-in defense mechanism against information based on anti-values (for the subject): it is perceived by the subject as alien and if it crosses the boundary of the thesaurus, then only in the form of its criticism $^{20}$.

Thus, within the thesaurus there is a differentiating principle of "own - stranger", but if you consider the thesaurus in its interaction with other thesauruses, the triad of "own - stranger - alien" becomes differentiating. Thus, one could argue that someone else, after all, to some extent his, that may be his, under certain conditions, as opposed to someone else, which in this place no thesaurus.

"Own - stranger" is the most certain value relationship that performs the function of social orientation. At first it is social: "my" - the one who belongs to me, "his" - what belongs to me, but at the same time and to the same extent "his" - from the circle to which I belong, "his" - of those things, properties or relationships on which I depend (my safety, pleasure, happiness, etc.) depend. In logical terms, the antonym of "one's own" is "not-one's own", and in value terms - "another's".

"Stranger", "unfamiliar" - are signs that are not only outside his own, but also opposed to his, and possibly - and hostile to him. It is in the paradigm of "one - another" that the reality of a person, group, community is perceived. "One 's own - alien" forms the core of a thesaurus and gives it social significance. This builds "pictures of the world", which gradually, as socialization and the acquisition of social identity of people are formed in their minds ${ }^{21}$.

The opposition of "own - stranger" is subject to consideration as a concept, an archetypal formation, as a manifestation of the internal differentiation of society and relationships between individual social

\footnotetext{
20 Луков В. А. Тезаурусы: субъектная организация гуманитарного знания / Вал.А. Луков, Вл.А. Луков. - М. : Изд-во Нац. ин-та бизнеса, 2008. - 784 с.

21 Луков В.А. А. Специфика гуманитарных наук и тезаурусная концепция / Вал.А. Луков, Вл.А. Луков // Информационный и гуманитарный портал «Знание. Понимание. Умение». - 2013. - № 1 (январь-февраль). - С. 75-85.
} 
groups, as images or feelings, and emerges as a coherent system of representations, worldviews and constructions of reality.

The basis of oppositions are the processes of existence of forms of objectification of value attitudes in social exchange, the system of norms and values, the way in which the world of man, group, community perceive in real life. The regulators of social relations are stereotypes characterized by the polarization and rigid fixation of such a dichotomy.

Opposition "own - stranger" manifests itself in the cognitive, affective and behavioral components of social identity and social perception: destructive attitudes in interpersonal relationships, social and psychological personal setting "altruism - selfishness, emotional and motivational orientations, and approval, features of social and psychological activity, types of "ego-protection" (hostility, aggression), manifestations of physical or verbal aggression against those whom a person or a person flax considers alien, in the levels and peculiarities of acceptance of others, the degree of social isolation of the individual and the group, the need for support from the environment.

\subsection{Phenomena of Intergroup Relations}

Ethnic stereotypes are an important component of social consciousness. In the structure of ethnic image, or ethnic stereotype, are distinguished ethnic educational formations (stereotypes, prejudices), values, psychological universals. By definition of V.S. Agyeev, they differ in brightness, relief, expressiveness, representation in the public and individual consciousness, practical acuity and relevance ${ }^{22}$. This explains the frequent appeal of researchers of social and national stereotypes.

In social stereotypes, according to the S.A. Kolosov, considered to be stable emotionally rich, value-defined image that is as standardized. The basis of its appearance are the psychological phenomena of generalization, generalization, categorization, schematization of information obtained in the experience. Social stereotypes as regulators of social relations are characterized by polarization of the qualities of the subject and object, as well as the rigid fixation of such a polar dichotomy ${ }^{23}$.

\footnotetext{
22 Агеев В.С. Межгруповое взаимодействие. Социально-психологические проблемы / В.С. Агеев. М. : МГУ, 1990. $-240 \mathrm{c}$.

23 Колосов С.А. Манипулятивные стратегии дискурса ненависти / С.А. Колосов // Критика и семиотика. - Вып. 7. - Новосибирск, 2004. - С. 248-256.
} 
According to E. I. Golovakha in society in recent years are increasing signs of social intolerance, which he considers antisocial personality disorder. It manifests itself wherever people's living conditions deteriorate. Instead, the search for culprits and social enemies is in place of finding ways to overcome this state of affairs. In the early years of "perestroika" polls showed that most of the respondents were intolerant of party functionaries and officials. As social, economic and political difficulties increased, intolerance became blurred, spread to representatives of different social groups, and became more aggressive ${ }^{24}$.

The social pathologies, including antisocial personality disorder, according to E. I. Golovakha leads vague and flimsy system of norms and values, massive violations of social adaptation. It is fair to note that the researcher notes that intolerance is a culture of confrontation, and consensus is a culture of compromise, tolerance, the ability to "yield to principles" for the benefit of society ${ }^{25}$.

In our opinion, one should pay attention to another phenomenon of the group - xenophobia. G. Breslav believes that the core of xenophobia is hatred of foreigners. He also notes the existence of a significant positive link between hate and ethnic intolerance, a natural consequence of which is social discrimination ${ }^{26}$.

In the words of G.S. Pomerantz: "Xenophobia in general clearly differentiates" us outsiders "with which the person is ready pobratatysya and" alien outsiders ", which - not $^{27}$.

The researcher also identifies xenophobia as a kind of human protective reaction that has a biological basis: it is a reaction to what is considered dangerous. He also clarifies that animals in the wild almost never show aggression towards what they think may be dangerous. Unlike animals, it is important for man to show aggression towards what or whom he regards as alien - physical or at least verbal, besides the aggression of xenophobes is necessarily motivated by something. "Aggression serves to mask the fear of the unknown. Therefore, the more developed in society (or in any group) xenophobia, the greater the fear of these people against the unknown.

\footnotetext{
24 Головаха Е. И. Социальные патологии посткоммунистического общества / Е.И. Головаха // Политическая мысль. - 1994. - № 4. - С. 36-45.

25 Головаха Е. И. Социальные патологии посткоммунистического общества / Е.И. Головаха // Политическая мысль. - 1994. - № 4. - С. 36-45.

${ }^{26}$ Breslavs G. et al. Vai m s esam ieciet gi? Sabiedrbas etnisk s ieciet bas monitoringa metodikas izveide / G. Breslavs, U. Bele, L. Derjabo, I. Piinska, J. Roze. Riga: Salus, 2008.

${ }^{27}$ Померанц Г.С. Кто такие «чужаки»? / Г.С. Померанц. - Знамя. 1991. - № 11. - С. 183-187.
} 
Therefore, it can be argued that xenophobia, as a kind of "us and them" effect, is a kind of human defensive response to what is considered dangerous.

In general, a clear distinction between "strangers" with whom a person is able to build even sufficiently close relationships, and "strangers", which is considered dangerous to approach, from one point of view, maximizes schematics of social perception between individuals and groups, and from another can act basis, a structural principle, such as in the thesaurus concept.

Judgments about strangers will inevitably be simplified over time by stereotyping, stigma and prejudice. The stereotyping of thinking establishes in the minds the understanding of who is "one's own" and who is "stranger", who is "one's relative" and who is "another's relative", who is "one's own" "stranger" and who is another's "stranger".

One of the conditions for the emergence of hatred is the separation of one's own group with other groups, that is, the emergence of the so-called "we-they" effect. Distinction can be made by virtually any criterion: based on ethnicity, nationality, political views or social status. G. Breslav, noting the variability of hate manifestations, also defines the diffuse nature of the object of hatred, noting that hatred is a derivative of social identity. The difference between one's own group and other groups often causes the member and other groups to be viewed in a negative context. They may even be considered a threat to their group or may be devalued based on their "differences" 28 .

M.M. Slyusarevskyy notes that "human"we"... older than "I". Therefore, the individual psyche is still not always able to withstand the social, the latter is often stronger than the individual. Individual consciousness depends on the generational layers of consciousness of the masses within which it functions; the personality is influenced by the quantified portions of the worldview concentrated in the so-called social stereotypes" 29 .

B.F. Porshnev group investigating the phenomenon of "we - they" pointed to the primacy of the origin of the image "they", for it is through the understanding of the term ("they" - is "not like us") community can recognize itself as such. He also gave a thorough analysis of the socio-

\footnotetext{
${ }^{28}$ Бреслав Г. Ненависть как предмет психологического исследования // Вопросы психологии - 2011. № 2 С. $136-148$.

${ }^{29}$ Слюсаревський М.М. «Ми» і «Я» в сучасному світі: Вибрані твори / М.М. Слюсаревський. - К. : Міленіум, 2009. - 340 с. - С. 113-120.
} 
psychological phenomena of the formation of subjective and group "we", but emphasized the primacy of the phenomenon of "they" ("alien"), which became a significant social fact for the development of sociality of the individual $^{30}$.

B.F. Porshnev speaking about the social and psychological content of selected categories, notes that in primitive society "we" - it's always "people" in the literal sense, that people in general, while "they" - not quite people. The name of many tribes and peoples in translation means simply "people." This again illustrates that in the psychological sense, "we" is a very difficult psychological category ${ }^{31}$.

Modern Ukrainian psychologist P.P. Ghornostay takes the phenomenon of "we" as a symbolic group role when individual identity is replaced by various forms of group consciousness, that person depersonalisation ${ }^{32}$.

According to I.C. Daniluk, creating an image of the group "We" can be understood as a determinant in stereotyping internal and external enemy ${ }^{33}$.

Awareness of the person belonging to a particular ethnocommunity, identifying his "I" to "we" disengagement "we - they" respect "their" and "other" communities, according to G.S. Lozko has a special place among the subjective symptoms nation and national consciousness, which can be somewhat arbitrarily called the result of self-knowledge of the representatives of the nation ${ }^{34}$.

Ethnic consciousness is defined as one form of relation of a certain ethnic group to other groups. According to A.M. Lozova, ethnic consciousness produces an ethnic image of the world $35,36,37$.

\footnotetext{
30 Поршнев Б.Ф. Противопоставление как компонент этнического самосознания / Б.Ф. Поршнев. М. : Наука, 1973. - 346 с. - С. 163-184.

31 Поршнев Б.Ф. Противопоставление как компонент этнического самосознания / Б.Ф. Поршнев. М. : Наука, 1973. - 346 с. - С. 163-184.

32 Горностай П.П. Психологічний феномен «Ми» / П.П. Горностай // Соціальна психологія. - 2006. № 2. - С. 88-96.

33 Данилюк І.В. Мова як чинник згуртованості групового «Ми» / I.В. Данилюк // Соціальна психологія. - 2008. - № 3. - С. 105-112.

34 Лозко Г.С. Етнологія України: філософсько-теоретичний та етнорелігієзнавчий аспект: навч. посіб. / Г. Лозко. - К. : АртЕК, 2001. - 304 с.

35 Лозова О.М. Психосемантика етнічної свідомості : Монографія / О.М. Лозова. - К.: «Освіта України», 2007. - 402 с.

36 Лозова О.М. Мова в етнічній картині світу / Лозова О.М. // Вісник Київського міжнародного університету. Збірник наукових статей. - Серія: Психологічні науки.- Вип. 13. - К.: КиМУ, 2009. - С. 110-123.

37 Лозовая О. Н. Психология этнического сознания в Украине: история, настоящее, перспективы / Лозовая О.Н. // Историческая психология: истоки и современное состояние : Монография / под науч. ред. И.Н. Коваля, В.И. Подшивалкиной, О.В. Яремчук. - Одесса: Одесский национальный університет им. И.И. Мечникова, 2012. - С. 115-129.
} 
Ethnicity is a mature group and exists as a stable system that opposes itself to everyone else on the basis of the distinction of "we are not us" ("they"), "our own - strangers", "best - worst" and so on. And this recognition of the ethnic collective of its unity is the main feature of the ethnic group, reflecting in the minds of people its existing integrity as a system. But ethnicity is a product not only of consciousness but also of human nature, a reflection of a certain physical or biological reality ${ }^{38}$.

Increasing interethnic tensions contribute to the manifestation of the most characteristic characteristics of the people inherent in the past, the adaptive ways of its behavior, which are entrenched as the most successful. Perceptions of them form an important part of ethnic identity, interact with the educational establishments and form connective structures of ethnicity, defining the ways of intra-group organization and mobilization of the group. In modern ethnopsychology, ethnic auto -stereotypes representations and characteristics of members of "their" ethnic group are distinguished, and ethnic hetero - stereotypes - images of representatives of "other" ethnic groups. As demonstrated numerous empirical studies almost always ethnic avtostereotypy differ significantly greater positivity, than ethnic heterostereotypy.

\section{CONCLUSIONS}

As a result of the theoretical analysis, we can conclude that hatred is a complex phenomenon of the human sensory sphere, which to a certain extent determines its existence. The category of hatred is interdisciplinary in philosophy, cultural studies, linguistics, personality psychology and social psychology.

With participant scientific opinion defines the ambivalent nature of hatred: on the one hand, irrationality, and the other - the rationality and necessity. It is determined that the object of hatred is usually blurred, mythologized, and hypertrophied. Hate is not an innate feeling, but a person's acquired life. Sometimes hatred develops in a person as a result of her ideas about how external circumstances affect the individual.

Poor development of phenomenology and hate issues is associated with the taboo of discussing this topic in society, as well as a number of moral, ethical and organizational problems associated with the study.

\footnotetext{
38 Лозко Г.С. Етнологія України: філософсько-теоретичний та етнорелігієзнавчий аспект : навч. посіб. / Г. Лозко. - К. : АртЕК, 2001. - 304 с.
} 
At present, there is no lapidary and uniquely worded concept of hatred, but summing up the diversity of thoughts, we can determine that hatred is a persistent negative feeling of the subject directed at another person, group of people, inanimate object or phenomenon that represents a real or imagined threat, or the subject's values. This feeling is characterized by the constant desire of the subject to inflict as much pain or suffering (up to the destruction) of the object of hatred, real or imagined, as possible.

It is determined that the predictors of hatred can be different factors of intergroup and interpersonal relationships, such as: effects of "we-they", "own - stranger", social and ethnic stereotypes, xenophobia and others.

At present, a lack of empirical basis for hate studies is causing some confusion in scientific research, which necessitates further fundamental and applied research.

\section{SUMMARY}

The paper highlights contemporary theoretical approaches to the study of hatred. The interdisciplinary nature of the problem has been identified: the category of hatred is considered in philosophy, cultural studies, linguistics, personality psychology and social psychology. The basic social and psychological connections within the framework of the polyparadigmal approach are outlined. The place of hate category in the system of interpersonal and intergroup relations was determined. An attempt is made to define the concept of hatred and differentiate it from other social and psychological categories. The place of hate category in the system of intergroup relations is determined. It is determined that hatred is a complex phenomenon of the human sensual sphere, which determines its existence. Hate has been found to have a unique neurobiological pattern of brain activity.

\section{REFERENCES}

1. Агеев В.С. Межгруповое взаимодействие. Социальнопсихологические проблемы / В.С. Агеев. - М. : МГУ, 1990. - 240 с.

2. Аминев Г.А. Историко-психологические предпосылки межцивилизационных конфликтов: юнгианский подход / Г.А. Аминев, Э.Г. Аминев, Цзинь Ван (г. Пекин), М.Н. Иванов, Л.Р. Шафикова // Пространство и время в восприятии человека: историко- 
психологический аспект : матер. XIV Междунар. науч. конф. - CПб. : Нестор, 2003. - Ч. 1. - С. 7-9.

3. Белинская Е.П., Тихомандрицкая О.А. Социальная психология личности : учеб. пособ. для вузов / Е.П. Белинская, О.А. Тихомандрицкая. - М. : Аспект Пресс, 2001. - 301 с.

4. Бреслав Г. Ненависть как предмет психологического исследования // Вопросы психологии - 2011. - № 2. - С. 136-148.

5. Головаха Е.И. Социальные патологии посткоммунистического общества / Е.И. Головаха // Политическая мысль. - 1994. - № 4. C. 36-45.

6. Горностай П.П. Психологічний феномен «Ми» / П.П. Горностай // Соціальна психологія. - 2006. - № 2. - С. 88-96.

7. Гумилев Л.Н. Этногенез и биосфера Земли / Л. Н. Гумилев. СПб. : Ленинградское Изд-во, 2011. - 560 с. - С. 25-27, 92-96.

8. Данилюк І.В. Мова як чинник згуртованості групового «Ми» / I. В. Данилюк // Соціальна психологія. - 2008. - № 3. - С. 105-112.

9. Иванов М.Н. Типообразующие соотношения архетипа «свой/чужой» и склонности к терроризму: психофизиологические предикторы: автореф. дис. на здобуття наук. ступеня канд. психол. наук : 19.00.02 «Психофизиология» / М.Н. Иванов - Уфа, 2004. - 22 с.

10. Кернберг О. Отношения любви: норма и патология / О. Кернберг. Пер. с англ. М.Н. Георгиевои.-М.: Независимая фирма "Класс", 2000. - 256 с. - (Библиотека психологии и психотерапии, вып. 76).

11. Колосов С.А. Манипулятивные стратегии дискурса ненависти / С.А. Колосов // Критика и семиотика. - Вып. 7. Новосибирск, 2004. - С. 248-256.

12. Лозко Г.С. Етнологія України: філософсько-теоретичний та етнорелігієзнавчий аспект: навч. посіб. / Г. Лозко. - К. : АртЕК, 2001. - 304 c.

13. Лозова О.М. Мова в етнічній картині світу / Лозова О.М. // Вісник Київського міжнародного університету. Збірник наукових статей. - Серія: Психологічні науки.- Вип. 13. - К.: КиМУ, 2009. C. $110-123$.

14. Лозова О.М. Психосемантика етнічної свідомості : Монографія / О.М. Лозова. - К.: «Освіта України», 2007. - 402 с. 
15. Лозовая О.Н. Психология этнического сознания в Украине: история, настоящее, перспективы / Лозовая О.Н. // Историческая психология: истоки и современное состояние : Монография / под науч. ред. И.Н. Коваля, В.И. Подшивалкиной, О.В. Яремчук. Одесса: Одесский национальный університет им. И.И. Мечникова, 2012. - C. 115-129.

16. Луков В.А. Специфика гуманитарных наук и тезаурусная концепция / Вал.А. Луков, Вл.А. Луков // Информационный и гуманитарный портал «Знание. Понимание. Умение». - 2013. - № 1 (январь-февраль). - С. 75-85.

17. Луков В.А. Тезаурусы: субъектная организация гуманитарного знания / Вал.А. Луков, Вл.А. Луков. - М. : Изд-во Нац. ин-та бизнеса, 2008. - $784 \mathrm{c}$.

18. Померанц Г.С. Кто такие «чужаки»? / Г.С. Померанц. - Знамя. 1991. - № 11. - С. 183-187.

19. Поршнев Б.Ф. Противопоставление как компонент этнического самосознания / Б.Ф. Поршнев. - М. : Наука, 1973. 346 c. - C. $163-184$.

20. Слюсаревський М.М. «Ми» і «Я» в сучасному світі: Вибрані твори / М.М. Слюсаревський. - К. : Міленіум, 2009. - 340 с. C. $113-120$.

21. Спиноза Б. Избр. произв.: В 2 т. Т. 1. М: Политиздат, 1957. C. $467-468$

22. Чужой [Электронный ресурс]. - Режим доступа : http://ecdejavu.ru/c/Chuzoy.html.

23. Шихирев П.Н. Современная социальная психология / П. Н. Шихирев. - М. : ИП РАН, КСП+, Академический Проект, 1999. $-447 \mathrm{c}$.

24. Экман, Пол. Психология эмоций / пер. с англ. В. Кузин.СПб.: Питер, 2010. - 336 с.

25. Allport G.W. The nature of prejudice. Garden City, NY: Doubleday Anchor Books, 1958.

26. Bar-Tal D. Collective memory of physical violence: Its contributions to the culture of violence // G. Salomon, B. Nevo (eds). Peace education: The concept, principles and practice around the world. Mahwah, NJ: Lawrence Erlbaum Associates, 2002, P. 27-36. 
27. Baumeister R.F., Butz D.A. Roots of hate, violence, and evil // Sternberg R.J. (ed.). The psychology of hate. Washington, DC: APA, 2005. P. 87-102.

28. Breslavs G. et al. Vai m s esam ieciet gi? Sabiedrbas etnisk s ieciet bas monitoringa metodikas izveide / G. Breslavs, U. bele, L. Derjabo, I. Piinska, J. Roze. Riga: Salus, 2008.

29. Breslavs G., Tyumeneva J. Toward operationalization of the hate concept: Is hate an opposite to love? // The paper presented at the 14th European conference on Personality, Tartu, July 16-20, 2008.

30. Fitness J. Anger in the workplace: An emotion script approach to anger episodes between workers and their superiors, co-workers and subordinates // J. of Organizational Psychol. 2000. V. 21. P. 147-162.

31. Kimberly Dozier Breathing the Fire: Fighting to Survive, and Get Back to the Fight.

32. McKellar P. Provocation to anger and development of attitudes of hostility // Brit. J. Psychol. 1950. V. 40. P. 104-114.

33. Semir Zeki, John Paul Romaya. Neural Correlates of Hate / Plos One. https://journals.plos.org/plosone/article?id=10.1371/journal.pone.0003556

34. Sternberg R.J. (ed.). The psychology of hate. Washington, DC: APA, 2005.

\section{Information about the author:} Bielavin S. P.

$\mathrm{PhD}$ in Social Psychology, Associate Professor at the Department of Psychology and Pedagogy of the Scientific and Humanitarian Institute of the V. I. Vernadsky Taurida National University 33, Ivana Kydri str., Kyiv, 01042, Ukraine 